ARTICLE

\title{
Masculinity and Institutional identity in South Cyprus - the case of 'I do not forget'
}

\author{
STRATIS-ANDREAS EFTHYMIOU, University of Sussex
}

\begin{abstract}
This paper explores Greek-Cypriot masculinity through the lens of 'I do not forget' and was triggered by personal experiences with educational and military institutions in South Cyprus. The aim is to put forward a theoretical framework enabling a better understanding of Cypriot conflict identities, using an enquiry into institutionalised identities. The iconic image of the mother of the missing persons is mobilised in understanding the inter-constitution of post-war Greek-Cypriot nationalism as based on explicit notions of victimhood, in which the military assumes a key role in ensuring national survival. Through a discussion of two chosen institutions as examples - schools and military - I highlight that gender discourses have played a vital role in the construction of these specific institutional identities. I am using the evolution of the above slogan to mobilise the idea of identity being transmitted and crystallised through interinstitutional dialogues. 'I do not forget' comes to be seen as operating through meticulous institutional support of constructions of national identity, mobilised through gender. The military takes up some of these impulses and constructs specific militarist masculinities.
\end{abstract}

Keywords: Cyprus, masculinity, militarism, institutional identity, 'I do not forget' national identity. 
Networking Knowledge: Journal of the MeCCSA Postgraduate Network, Vol. 4, No. 1 (2011)

\section{Introduction}

This paper introduces a discussion of Greek-Cypriot ${ }^{1}$ masculinity through the lens of 'I do not forget' (a post war Greek-Cypriot slogan), triggered by a personal story, which I present in turn. Specifically, I am interested in locating points whereby Greek-Cypriot masculinity is shaped and exemplified. I do so by acknowledging and embracing the large spectrum through which nationalism mobilises and naturalises ideals of masculinity throughout society. My aim is to provide a theoretical framework through which Cypriot conflict identities can be understood using an enquiry into institutionalised identities. I am using the evolution of the discourse of 'I do not forget' to mobilise this idea of identity being transmitted and crystallised; made static in this sort of discourses. There are two main objectives in this article. One is to reveal the masculine-based nationalism and the other is to show the process through which masculinity itself is lived within the modality of Greek-Cypriot nationalism, thus how masculinity is naturalised and nationalised by the means of institutional support. While theoretical and methodological considerations will be discussed, this will always lead to underlining threads between the discourse of 'I do not forget', Greek-Cypriot masculinity and militarism. I claim that there continues to exist a 'post-referendum conflict culture' in which militarism (in a distinctly defensive posture) and masculinity serve an important function. Furthermore, the apparent lack of efficacy of the border crossings ${ }^{2}$ is used to illustrate that nationalism and masculinity currently operate synonymously in the construction of Greek-Cypriot identity and does not only directly correspond to the political level.

1 In this article I understand 'Greek Cyprus' and 'Greek-Cypriots' as nationalistic constructed basis of drawing divisions. This is further explained later in the article and in more detail on page 16. Therefore while 'South Cyprus' is used in refereeing to the geographical understanding of the South part of Cyprus as place and as people, 'Greek-Cyprus' and 'Greek-Cypriots' is used as a constructed idea. This distinct use between South Cyprus and Greek Cyprus will become clearer towards the end of the paper.

2 In April 2003 the then Turkish-Cypriot president (Rauf Denktas) opened up the border between North and South Cyprus, making possible the free-flow of people for the first time since the border was established (1974), taking Greek-Cypriots by surprise. Such a political intercession could have decisively contributed to a collective paradigm shift of desire for peace and reconciliation but it has not. For an extended analysis s of this political initiative and its consequences, see Hadjipavlou (2007). 
This article begins by describing the emergence and evolution of 'I do not forget' as an institutionalised slogan and discussing a personal encounter in order to highlight how nationalism in South Cyprus, emerging from the post-war [1974] era, was one of victimhood. In foregrounding the way mothers of missing persons have been mobilised in order to construct a victimised Greek-Cypriot post-war national identity, 'I do not forget' may be seen as an expression of a nationalist discourse of victimhood. Here, the institutional facet of identities is highlighted and the concept of institutional identity is in turn theoretically located, illustrating that such discourses are institutionally thought and constructed, resulting in them operating in these definitive ways. Following the discussion of two institutions as key examples - schools and military - it becomes apparent that such discourses have played a vital role in the construction of the aforementioned institutional identities. Thus, they need to be approached from an enlarged understanding in order to encompass institutional constructions that operate in general Cypriot life. Here, the institutional support of the discourse of 'I do not forget' is seen as resulting to the operation of it as a master discourse of victimisation. Thus, the slogan is seen as mobilised by and mobilising institutions, also operating within institutional processes of constructions of identity and filtered throughout Greek-Cypriot society.

As a result, these particular notions and understandings of a victimised idea of nationhood and, subsequently, selfhood, within politicised femininities and masculinities, have been naturalised and nationalised in the whole of society. This came to be at the expense of postwar Greek-Cypriot political goals ${ }^{3}$, which have sought to create an entrenchment of identity providing a particular frame of reference; we have been victims of the enemy and that, we will not forget.

3 Examples of such political goals are the dominant political agenda and projection regarding the Annan plan, which was against reunification under the 'Annan plan' (officially Annan III) terms. In this political agenda it was often emphasised that accepting the plan would have been 'selling' one's country to the enemy and thus 'forgetting' the military offensive of 1974. Another example is that following the border openings of April 2003, by the Turkish Cypriot president Rauf Denktas, there was a GreekCypriot political and institutional discouragement of crossing the boarder. Subsequently, the ones who did cross were characterised as traitors of the nation. 
Networking Knowledge: Journal of the MeCCSA Postgraduate Network, Vol. 4, No. 1 (2011)

\section{'I do not forget'}

'I do not forget' (in Greek: « $\Delta \varepsilon v \xi \xi \chi v(\omega ́ »)$ in popular discourse represents 'I do not forget what the Turks did to us'. As an institutionalised slogan, it appears on the cover of primary school course books and in other places, such as above pictures of the war, scenes of the North side of Cyprus and, more recently, in an increasing number of public places, such as stickers placed on traffic light poles. As a post-war Greek-Cypriot slogan, 'I do not forget' is a phrase that appeared post-1974 in Greek-Cyprus. Although perceived as emerging 'out of nowhere', it was institutionally produced through discourses of power used by the State and its associated communicative agents. It soon came to form one of the predominant Greek-Cypriot post-war identity claims.

For example, schools in South Cyprus are an intact Greek-Cypriot institution and communicative agent of the State, within a highly centralised educational system 'based on a fixed curriculum for all schools that is controlled by the Ministry of Education' (Christou 2007: 712). Following the 1974 invasion, Christou (2006: 289) explains, "the slogan "I do not forget" ( $\Delta \varepsilon v \xi \xi \varepsilon v \omega ́$, Den Xechnó) began to appear in the classrooms of all Greek Cypriot high schools and, along with pictures from the occupied part, became a permanent feature of school life.' As she reminds us "I do not forget and I struggle" has been 'a primary goal in the Greek Cypriot educational system' (Ibid: 291).

What is at stake here, is the political institutional presence behind 'I do not forget'. It is a discourse created in the course of the Greek-Cypriot post-war political initiatives, through which particular institutionalised identities were transmitted to the public.

In this article, I approach 'I do not forget' as the main tactic used to produce GreekCypriot institutional discourses of identity and analyse how institutional support of identity produces and sustains master discourses. As noted above, I am using this slogan to mobilise this idea of identity being transmitted and crystallised - made static - in this sort of discourse. In presenting the following personal anecdote, I use it as a platform for considering post-war 
Greek-Cypriot nationalism through the lens of 'I do not forget'.

In 2003, during my military service as a soldier in the National Guard, I suggested the following to my Captain: 'Is it not realistically useless that a Greek-Cypriot army even exists? In the case of war, we will be fighting Turkey; one of the biggest military powers in the world! Also, [I added] it is even worse if we try to resist and not surrender, as people will die and, in any case, we are going to lose'. His answer was evocative of the interconnections between militarism and nationalism: 'Stratis, if you are walking with your girlfriend in the street and another man, much bigger than you, comes and disturbs your girlfriend, are you not going to do anything because he is bigger than you? Or are you going to stand on your feet, as a man, and protect your girlfriend?'

In the metaphor my Captain used to justify the military's existence in the South part of Cyprus, the aggressor, the physically strong man who is bigger than the boyfriend represents Turkey, and the weaker man, who is the protector, represents the Greek-Cypriot army. The latter will, even if much weaker than the Turkish army, protect the powerless girlfriend, who is here used as a symbol of the Greek-Cypriot nation, conceived as feminine and in need of protection.

Below I provide a brief account of the emergent post-war Greek-Cypriot nationalism as a nationalism of victimhood, conceptually anchored onto the mothers of the missing persons.

\section{Victimisation in Greek-Cypriot post-war national consciousness}

National survival constituted the pivotal axis of post-war Greek-Cypriot nationalist imagination, giving rise to a nationalism of victimhood, in which the military assumed a key role in ensuring national survival. The post-war Greek-Cypriot nationalistic slogan 'I do not forget' was previously identified as a focal element in the creation of a Greek-Cypriot consciousness of victimhood against the Turkish aggressor (for further discussion, see Bryant (2005), Yakinthou (2008) and Hadjipavlou (2006)). 
Yakinthous' (2008) discussion of the iconic image of the mother of the missing husband, brother or son provides a useful point of departure in understanding the inter-constitution of Greek-Cypriot nationalism and victimhood. She mentions, 'the symbol of the tormented woman (mother or wife) dressed in black and holding a photo of her missing loved one to a silent sky is the most powerful symbol of Greek-Cypriot suffering' (ibid: 16). Also Christou (2006: 294), in reflecting on her interviews with Greek-Cypriot students in relation to the discussed slogan, notes that the most sacred icon of struggle for youth today are the mothers and wives of the missing Greek-Cypriot men. These women, she writes, are 'black- clothed and tragic figures, [and] were mentioned by almost every student I talked to as the purest expression of hope, struggle, and resistance' (ibid). Feminist literature contributed to the understanding that in nations, women's reproductive role is used to articulate policies of national survival (see YuvalDavis 1998 and particularly on Greek-Cypriot women's role in the EOKA movement see Anthias 1989). The mothers of the missing persons have been mobilised to construct a victimised GreekCypriot post-war national identity. 'I do not forget' is a master discourse of victimisation, in which the understanding of these women as powerless and the resulting culture of fear and victimisation is cultivated.

The post-war Greek-Cypriot mother - exemplified in the discourse of the mothers of the missing persons - highlights a broader national powerlessness, which has ironically become powerful in representational terms. Borrowing Christou's words, this explains why the mothers of the missing persons 'have come to represent not only the strength of the Greek Cypriot collective memory [...I do not forget....] but also a form of unattained struggle [... I do not forget and I struggle...]' (2006: 296). Within the conflict identities in Greek Cyprus mobilised by the State, human pain and suffering of the mothers of the missing persons were instrumentalised in promoting a particular political agenda, which was underlined and partly built on politicised femininities and masculinities (see Anthias, 1992; Cockburn, 2004; Hadjipavlou, 2006 and Hadjipavlou and Mertan, 2010).

These associations between Nation, femininity and powerlessness have in turn aided in 
reproducing certain post-war masculinities. In this space of victimised national definition, the manufacturing of masculinity should be highlighted, yet also the construction of militarization through these discourses of victimhood. In analysing the idea of institutionalised identities in the next section, I argue that Greek-Cypriot institutions in the post-war period have been central in forging connections between a nationalism based on victimhood - largely articulated through 'I do not forget'- masculinity and militarism. Below I provide a theorisation of this connection, which is in turn used as a theoretical framework in the understanding of two examples: schools and military.

\section{Institutional identities}

The 'organising idea of identity' (Bulmer and Solomos, 1999: 81) can play a specific and central role in talks around gender and nationhood. Moreover, in a divided conflict society, the idea of institutionalised identities provides a better understanding of the apparatus through which identities exist and are acquired, claimed and allocated within power relations, therefore enabling an understanding of the process through which identity can become a 'means and end in politics' (Jenkins, 1996: 128). In emphasising the institutional facet of identities, I intend to show the conditional and situational character of Greek-Cypriot conflict identities, thus taking cognisance of the ways in which national and gender identity interact in complex and intersecting ways to structure Greek-Cypriot people's images of themselves and others.

Institutions attempt to establish institutional identities, which they assume are adopted by individual citizens. Here, individuals are believed to retain some agency in the 'performance' (Butler, 1997) of their identities, thus selectively appropriating aspects of pre-determined discourses of identity and contextually situating them. However, people are not always in a position to 'choose' who they are or how their identities may impact others or have related social consequences. Hence, I seek to understand nationalism as a set of practices and discourses that are complicit in identity construction. Understanding identity as a representation of 
organisational structure means understanding identity as a practice of politics; consequently, 'institutional identities' must be understood as identities that are made through the orientation of institutional goals or activities and as corresponding to distinct political views and aims.

In identifying links between institutions, discourses and identity, I adopt a critical discourse analytic approach, which argues that people's interactions in social situations reflect existing macro-social forces (Benwell and Stokoe, 2006). Rather than seeing these macro-social forces through a version of 'institutions' which assumes a coercive, oppressive and one-sided imposition of power (see e.g. Habermas, 1987), I adopt a multi-sided definition of power, treating it as a 'happening of experience', which is achieved through persuasion, consensus and complicit cooperation (see e.g. Foucault, 1972 and Gramsci, 1971).

Institutions are 'an integral part of the social construction of reality, with reference to which, and in terms of which, individuals make decisions and orient their behaviour' (Jenkins, 1996: 126). Furthermore, they are like identities, 'emergent products of what people do as much as they are constitutive of what people do' (ibid: 128). I argue that institutions provide normative specifications of how things are done; through this, identities arise in how we do things, as this is who we are. Then they do not "exist in any sense "above the action" (ibid: 128).

Institutions allow us to think and imagine social life through their patterns and regularities. Berger and Luckmann (1973) indicate that the very existence of the institution, as an axiomatic part of the social world - 'the way things are' - is the primary form of social control. I interpret this in the way that imagining things in a different way to the one offered by institutions is difficult to encompass, but not unattainable and thus not deterministic. Moreover, I understand institutions in an analogous way to Foucault's notion of government, which structures 'the fields of action of others' (1983: 221). It is a 'question not of imposing law on men, but of disposing things: that is to say, of employing tactics rather than laws, and even of using laws themselves as tactics to arrange things in such a way that, through a certain number of means, such and such ends may be achieved' (Foucault, cited in Scott, 1995: 202 - for original see Foucault, 1991). 
The social world and the reality in which it is interwoven is a world of institutionalised practices.

Collective identities are institutionalised: as 'ways of being' they are 'the way things are done' (Jenkins, 1996: 133). Drawing from Jenkins (ibid), if we are to conceptualise identity as a process, then collective identifications must be institutionalised processes. Under this conceptual umbrella, national identifications are institutionalised, so are national specific gender identifications. This is not to say that institutions are themselves collective identities (or that this may not be possible) but, by borrowing Barth's (1969) term, they are generative of identifications. In Greek-Cyprus's institutional structures, they establish the tropes through which one acquires a Greek-Cypriot identity.

As pointed out above, 'I do not forget' appeared post-1974 in Greek-Cyprus, seen, in a sense, as emerging 'out of nowhere', although it was clearly institutionally produced through the power of Greek-Cypriot institutions, and soon became one of the predominant Greek-Cypriot post-war identity-claims, (see Christou, 2006, 2007 and Yakinthou, 2008). However, it must be noted that Greek-Cypriots have never been coerced into accepting that they should 'not forget'. Rather, it is a slogan that came into existence, was acquired, claimed and allocated through persuasion and consensus. The workings of 'I do not forget' operate in settled and repetitive ways (also through imaginary, for example, the slogan being accompanied with pictures of the war) in which politicised institutions persuade the population to approach the conflict understanding, through this specific frame of reference: 'I do not forget'. This slogan enhances the construction of Greek-Cypriots through this identity, by being used and consolidated in institutions they compulsively attend, such as schools and military.

Drawing a distinction between how 'I do not forget' has been transmitted through these two institutions, is not only a matter of distinguishing the ways these institutions have mobilised 'I do not forget', but also the ways in which 'I do not forget' has worked towards mobilising these institutions. Hence institutions have mobilised 'I do not forget' by cultivating particular frames of reference and coinciding identities, yet ' $I$ do not forget' has also created master 
discourses in which these institutions were mobilised. The use of 'I do not forget' in schooling is addressed first, and, subsequently its uses in the military.

\section{'I do not forget' - From school to army}

The role of educational systems in fabricating and reproducing discourses of nationhood and national identity has long been documented (Kedourie, 1994; Calhoun, 1997). Schools are seen as spaces where political struggles are uttered and propagated. In post-war Greek Cyprus, the political goal remained overt and, as a process, familiar to the nationalist discourse. Nationalist politics have rested on the belief that education is the main vehicle for cultivating a common national goal. Curricular changes by the Ministry of Education after 1974, Christou (2006, 289) explains, directed teachers to incorporate in their courses references to the war events, the plight of Greek-Cypriot refugees and the importance of remembering the part of Cyprus occupied by Turkey. Moreover, Greek-Cypriot school everyday life is infused with commemorations of the war and the Cyprus conflict. State-funded schools 'have sought to educate a new generation of Greek Cypriots by helping them to remember the occupied part of the island and to maintain the struggle for a unified country' (Christou, 2006; 286). Shortly after the invasion and war of 1974, the slogan 'I do not forget' began to appear in classrooms and pedagogical material provided by the State, often illustrated with scenes of the now lost North part of Cyprus. This rapidly became a permanent feature of State-funded schools. Later, the slogan was modified to 'I do not forget and I struggle', 'in order to render its meaning more active and instructive' (Christou, 2006: 289). Even more recently, in 2001, the slogan was upgraded for a second time ${ }^{4}$ to 'I know, I do not forget and I struggle. ${ }^{5}$ The impact of this post-war pedagogy and political strategy 'on the

4 In October of 2001, as Christou (2006: 291) notes, the Ministry of Education and Culture sent a directive to elementary schools titled "Upgrading the goal of "I know, I do not forget and I struggle". The memo noted that several inquiries showed a relative decline in student interest and knowledge about the occupied part of Cyprus, hence requesting teachers to dedicate some teaching time to this goal. For an extended analysis of the new slogan see Christou (2006: 292-3).

5 Given that the slogan has been evolving, when referring to 'I do not forget' in any form from this point onwards I will be referring to the 'I do not forget' as a policy and to 'I do not forget' as the general discourse and not to any particular stage of its evolution, except when specified otherwise. 
new generation of Greek-Cypriots (born after 1974) is, of course, of national importance because it signals the creation of a new national imaginary attached to the urgency for national survival' (Christou, 2006: 290; my emphasis).

In this conceptualisation of the Nation as victimised and in constant danger, militarism is located as the safeguard and defensive shield for protecting and preserving the Nation. Thus, the mothers of missing persons and the general discourse of victimisation cultivated and anchored around 'I do not forget and I struggle' mobilises the operation of the broader masculine discourse of a defensive Nation. In this Nation, men-as-soldiers, alongside military and political choices, ensure that injustices of the past will not be repeated and that justice will be sought as 'I struggle'. As Nagel (1998: 252) argues, 'the 'micro-culture' of masculinity in everyday life articulates very well with the demands of nationalism particularly its militaristic side.'

Subsequently, in this ontology of danger, the institutionalisation of this particular militaristic and masculinised self-understanding, which results from the culture of victimhood and fear that framed the entirety of the nationalist discourse since 1974, ensures that the crossings (which occurred since the opening of the borders in 2003) become an insignificant sociological fact. In this setting, there is a related inability to relinquish this culture of fear that anchors Greek-Cypriots in a compulsive defensive situation.

Institutions, in providing institutional identities, offer particular sets of experiences through which individuals understand and organise the social reality around them, but also make available the meanings that any experience can assume and be ascribed to. In essence, identity is a construct, yet people do collectively seek to identify themselves and others. Identity continuity therefore necessitates the positioning of a meaningful past. 'Individually 'the past' is memory; collectively, it is history' (Jenkins, 1996: 28). Although fundamentally memory and history are constructs (Hobsbawn and Ranger, 1983), they remain important facets of identity. Hobsbawn and Ranger (ibid) illustrated that memory is a function of resistance in nationalism, as the creation of the Nation itself is predicated on the act of constructing a single (emphasis on the 
specific institutional narrative in this case, but official narrative in general) historical narrative that recalls the struggles and glories of the Nation.

Individual and collective identities in Greek Cyprus become consistently remedial to each other, through the institutionalisation of identity producing master discourses. Then, in Greek Cyprus, 'the relationship between individual and collective pasts is a complicated one that writes individual hopes into collective traumas' (Bryant, 2008: 405). What we are asked not to forget is that we were victims once and this defensive shield will ensure that we will not be victimised again. As Bryant (2005: 56) argues 'institutions of memory that have permeated life in the south for 30 years have been aimed at the constant reliving of trauma, rather than at overcoming it'. She explains that 'many refugee organizations, committees of relatives of missing persons and even political parties all develop, sustain or symbolize narratives that produce ... a compulsive repetition of the site of trauma' (ibid). As Yakinthou (2008) illustrated, this stand was crystallized in the slogan of « $\Delta \varepsilon v \xi \xi \varepsilon \nu \nu$ »» ('I do not forget').

I suggest that the feminine articulations of powerlessness and hopeless victimhood, conceptually anchored onto the mothers of the missing persons and crystallised through 'I do not forget', were mobilised for the production of politicised masculinities. While this poses an issue both for Greek-Cypriot men and for the institutionalisation of identity in Cyprus, in gendering nationalist discourses, one should not overlook the construction of militarisation through these discourses throughout Greek-Cypriot society.

Thus, I argue that the casting of the Greek-Cypriot nation as a victim constantly threatened or at risk, served to naturalise the very militarisation of Cypriot life. Ultimately, in this particular discursive space of victimised national consciousness anchored around 'I do not forget and I struggle' the discourse of 'A $\mu v v \alpha$ ' (national defence) has operated as the predominant form of 'A $\gamma \omega v$ 'ío $\mu \alpha$ ' (I struggle). Moreover, regarding the opening of the borders in 2003 , there is a potential feminisation of identity through the enabled crossings.

At the outset, we must consider how dispensing of the historic subjectivity of 'not forgetting' - which as pointed out above, is a repetition on the site of trauma - would weaken the justification for perpetuating the struggle, and create space for an increased humanitarian 
understanding and empathy towards the inhabitants of the North site. Crossings can be perceived at the conceptual level as a feminisation of collective and individual identity since slipping away from a defensive stance, i.e. 'forgetting' represents emasculation and demasculinisation of the Nation and its men. As one male Greek-Cypriot informant regretfully mentioned recently: I have attempted to cross the border a few times, but when I get on the crossing-point something happens inside me and then I just can't, it is something within myself. Here, the role of the mothers of the missing persons has been facilitating in how-to-do-gendering and shaping the representation of post-war Greek-Cypriot national identity. As Yakinthou, (2008: 17) discusses 'a number of researchers have established that the representation of the missing persons has a very important role in defining the Cyprus conflict for and by Cypriots' (see Sant Cassia, 2005, 2006 and Papadakis, 2005). Therefore, the issue of the missing persons 'is woven deeply into the post-conflict societal structures.' (ibid).

Similarly, as Demetriou (2007: 999-1000) observes, the nationalistic arguments, which soon after the opening of the borders, became visible in slogans appearing near the checkpoints, were declaring: one should 'not need a visa to visit one's own house'. 'The order of the verb here [first person singular] is significant, because it harks back to the older rhetoric of the 1980s campaign against losing the memory of 'our lands', entitled 'I do not forget". She further argues that the 'universalized 'I' thus makes traitors of those who choose to differentiate themselves from it, either because their identity is not predicated on refugee-hood as a generalized mode of being, or because refusing to cross is for them not a matter of "pride".

One must then consider identities, which are 'imagined does not mean they are imaginary' (Jenkins, 1996: 28). For example, I remember the t-shirts we used to wear in school, on which the North site of Cyprus was portrayed, dripping blood, with the heading 'I do not forget' ${ }^{6}$. Likewise Christou (2006: 286) notes how Greek-Cypriot schools 'are decorated with posters that

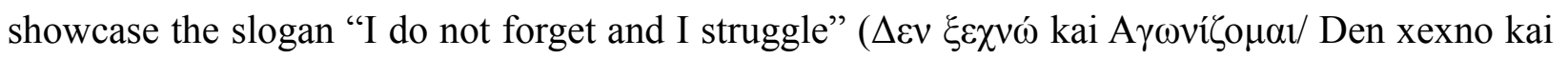

6As Christou (2006: 302) informs us "the phrase "I do not forget" along with the image of the island bleeding was actually a creation by the Greek author Nikos Dimou, who owned an advertising agency in 1974. Dimou explains on his website: The « $\Delta \varepsilon v \xi \varepsilon \chi v \omega ́ »$ symbol was created on August 14, 1974, the day Attila II cut Cyprus in half.' 
Agonizomai)'. As she further notes, such notions are expressed in the teaching of history, literature, the arts, and other activities. Far from imaginary, the 'Other' is evoked and constructed in the process of victimising the nation, which can be observed at the current cultural level of Greek-Cypriot everyday life. Under institutional master discourses, individual and collective identities are processes uncompromisingly crafting each other, in correspondence of facilitating and guiding collective action.

Institutionally created identities do not remain within the reach of institutions; they outline the modality of social life. One does not have to encounter the Greek-Cypriot culture much before starting to notice stickers stating 'I do not forget', produced and placed by individuals and groups on numerous sites, from traffic lights to house windows. Refugee organisations use 'I do not forget' as an emblem to social networking groups (on Facebook, for instance) called 'I do not forget' and the slogan shapes the conversational activity in GreekCypriot everyday life to the extent that people use it as a statement in politically oriented conversations. Institutional identities aim for a transmission to the population in the creation of culture. It is within this culture, then, that the military is placed as a rite of passage (Goffman, 1963 ) in the life of a Greek-Cypriot man.

At the outset the military mobilises 'I do not forget' in constructing particular nationalist masculinities. However 'I do not forget' also mobilises the military as an institution within Greek-Cypriot society. I maintain that institutional structures establish in South Cyprus the tropes, by which one acquires a Greek-Cypriot identity and as in the case of 'I do not forget' what is at stake is that there is a political institutional apparatus behind it. Yet, the slogan cannot be traced to a single institutional setting; rather, this discourse and its resulting identity construction can be seen as taking effect through inter-institutional dialogues, without ever being solidified to a singular institutional setting.

The military remains discursively central in constituting a magma of inter-institutional dialogues resulting in the construction and projection of these identities. I take the position that 'I do not forget' operates through meticulous institutional support of particular constructions of 
national identity that are mobilised through gender and that the military takes up some of these impulses and constructs specific militarist masculinities. This is an understanding that illustrates the bringing together of these institutions in the workings of 'I do not forget'. Thus, institutional support of identities further produces master discourses such as 'I do not forget'; these are then discursively communicated to the population through a bundle of institutional settings. In this practice the processes of institutions are themselves mobilised. I suggest that, in conflict societies such as Greek Cyprus, institutionalised identities do not merely form individual and collective identities; rather, institutionalised identities create master discourses in which individuals, collectivities, institutions and conflicts are created, shaped and configured.

Furthermore, 'I do not forget' does not feel strange to Greek-Cypriot citizens; rather it feels known and familiar. It has become, for most Greek-Cypriots, an inseparable way of being Greek-Cypriot. 'I do not forget' has become an identity with a specific frame of reference, which Greek-Cypriots do not think about but one they only think through. The power of institutional support, as analysed in the next section, is not only to bring about identities, but also to place them as hegemonic in oppressing and thrusting aside other possible identities and to naturalise and ossify the selected identities throughout society in a way that they will shape the modality of social life. This is by individuals experiencing them as taken for granted and common sense (Gramsci, 1971; Connell, 1995), without space for the suspicion of where these identities emerged. 'I do not forget' is an all-encompassing point of identification in the idea of GreekCypriot nationhood. It depicts 'common sense' realities in identities as modes of experience.

\section{Institutional naturalisation of identity in South Cyprus}

A key aspect of naturalisation is that it necessitates institutional support. Naturalisation of identities is not configured through everyday culture, although to some extent they may be reconfigured in its activity. Nonetheless, identities come to be experienced in a naturalised form by being institutionally configured and then filtered down to the population by the creation of 
culture. In this understanding of identity, national identity 'does not arise out of nothing, and does not exist in a social vacuum' (Ozkirimli, 2005: 32). Rather, national identity and masculinity are produced and imposed by a whole range of institutions.

The logic behind naturalisation is as follows: if differences between diverse national and gender groupings are 'cultural', then they are open to modification and change. But if they are 'natural', then they are permanent and fixed (Hall, 2001). Naturalisation of identity as a process can therefore be utilised as a 'representational strategy designed to fix 'difference', and thus secure it forever' as explained by Stuart Hall (ibid: 245) in reference to race.

Naturalised identities are an important political tool as they are 'closed' identities and are not as pliable as other identity formations to be reconfigured by individuals experiencing them. For instance, with the 'naturalisation' of national identity, national values are no longer seen as social or ideological values and instead appear as facts of nature; they become taken for granted, common sense and hegemonic (Ozkirlimli, 2005: 32-33). This 'ultimately turns the language of national identity into a language of morality, and renders nationalism the very horizon of political discourse' (Billing, 1995: 10).

Still, naturalisation is an active process; a making of identity that is always open to institutional reconfiguration, although naturalised discourses of identity appear as benign and passive. South Cyprus presents an important site in which to see the workings of these processes as described by theorisations of naturalisation, as we can notice how it is a benign and passive process resulting to the re-entrenchment of Greek-Cypriot identity as being different from Turkish-Cypriot identity. This was achieved through the institutionalisation of national identity, where amongst other ways, the State enhanced and reproduced the notion of Cypriots being Greek, through State-controlled education, for example in teaching Cypriot history as an extension of Greek history. This naturalising process was so effective that to speak of GreekCypriots today is to say that Turkish-Cypriots do not historically have a rightful place in Cyprus. Thus, both Self and Other have become homogenous and static entities. Such understanding of 
Cypriots as Greek-Cypriots is the end of a successful naturalising process that resulted in the vast proportion of the population unquestionably understanding themselves as Greek-Cypriots. This identity, imagined through a primordial framework, is thus understood as a natural and biological category extending in a cleansed form from the Ancient Greeks to today (for further analysis, see Mavratsas, 1996, 1999 and Papadakis, 2008).

While in Greek Cyprus, national identity is fixed and secured, masculinity in its cultural form does not fall back on institutional naturalisation. The 'real', and hence natural, post-war, Greek-Cypriot man evolved around the idea of war heroes, through which attributes of bravery, patriarchy and homophobia were established. On the other hand, Turkish-Cypriot men are perceived to be cowardly, barbaric and dangerous, due to them being uncivil (conceptually linked to the Ottomans and characterised as Attilas ${ }^{7}$ ). Despite this, Greek-Cypriot men, even if importantly outnumbered, are portrayed as having the ability to defeat the Turkish-Cypriots in a future war since they are 'naturally' excellent soldiers, descendants of ancient Greeks and henceforth real men fighting for a 'real' purpose, being of course 'naturally' on the right side.

Institutional genuses of identifications are elemental in the naturalisation of purpose. Naturalising identities means naturalising ways of seeing, valuating and understanding. Naturalising understandings means ascribing predetermined frames of reference for how experiences should be understood. In doing so, purpose emerges as stipulated by the particular identities.

Naturalising masculinity in Greek Cyprus implies naturalising frames of reference through which a 'real' Greek-Cypriot man should understand any experience, but it also makes available meanings that any experience can assume and be ascribed to. In understanding oneself as a 'real' Greek-Cypriot man, there is a specific understanding of a man's reason, his sense of duty towards the Nation and the future the Nation should hold; hence 'the predictability of the nationalist future which contains no surprises' (Spyrou, 2002: 101).

7 Attila is a Greek-Cypriot term characterising the Turkish invasion of 1974, which was linked to the action of Attila the Hun. Consequently, Turks and Turkish-Cypriots are often characterised by Greek-Cypriots as Attila's. 


\section{Naturalisation of experience in the institutionalisation of identity}

'I do not forget' provides an important contribution to understanding the materialisation of the above theorisations. 'I do not forget' is a discourse not routed in individual experience, since most people positioning themselves through it nowadays have not been directly involved in the war. As noted, discourse is here largely understood through Stuart Hall's definition: 'sets of ready-made and reconstituted 'experiencings' displayed and arranged through language' (Hall, 1977: 322). This is understood to mean that people live and experience life through discourses; discourses impose frameworks that limit what can be experienced or the meaning that experience can assume, thereby influencing what can be said or done. Hall (1977) conceptualises discourses as sets of experiencings, yet understandings of gender in Greek Cyprus are constructed through claims of national identity operating at and across different levels of linguistic and cultural experience. Therefore, distinctions must be made in terms of the construction of experience at different levels.

One distinction is related to the construction of experience between institutionalised and personal levels of identity. Thus, there is a distinction at the level of how experiences are constructed and conceptualised at the institutionalised level of identity and at the personal one. I maintain that in the case of 'I do not forget' these two levels of conceptualisation of experience coalesces between them, as well as in the structures of collective and personal consciousness generated therein.

'I do not forget' selectively uses individual and collective past experiences - and in some cases, the myth of experiences - in fabricating a set of experiencings (term borrowed from Stuart Hall, 1977) through which it constructs a particular frame of reference. This is naturalised in the institutionalisation of identity. Hence, in 'I do not forget' there is no singular, individual and personalised experience, but rather individual experiences that are produced and manufactured within the institutional identity of 'I do not forget'. 
One can experience such institutional discourses and then take on that identity. However, these institutional identities can be abstracted from actual individual experiences. As in the case of 'I do not forget', it contains sets of experiencings, which appropriate tropes from the myth of the war, the myth of the 'Other' and the myth of a desired fastidious Greek-Cypriot identity. Then, institutional discourses, in fabricating sets of experiencings, can create experiences that are abstractive of actual experiences, albeit being experienced as 'natural' by being discursively communicated to the population, through the consolidation of an identity, which entwines fabricated sets of experiences to individual realities.

Given the above argument regarding the interplay between institutional and personal experiences entwining realities, what is at stake is the process through which personal, institutional or abstractive experiences are established as dominant and hegemonic. In the following section, I suggest that there is a discursive play of appeals in which some discourses become successful and some are set as inferior to the hegemonic model or are thrust aside.

\section{Institutional hegemonies}

In conceptualising identity, I adopt Stuart Hall's (2000) perspective as it combines elements of agency and determinism. His concept is both 'a strategic and positional one'. We exist at the 'intersection' of a continuous discursive play', 'identities are thus points of temporary attachment to the subject positions that discursive practices construct for us all' (Hall, 2000: 19). This framework of thinking 'accepts that identities are never unified and, in late modern times, increasingly fragmented and fractured; never singular but multiply constructed across different, often intersecting and antagonistic, discourses, practices and positions' (Hall, 2000: 17).

Discourses of Greek-Cypriot national identity and masculinity are here seen as hegemonising. Like other co-existing multiple discourses, discourses of Greek-Cypriot national identity and masculinity are about power and domination. Thus, they legitimate and produce hierarchies of discourses by dominating other discourses or, according to Brubaker (1996: 20-1), 
in referring to the discourse of national identity, by dominating alternative political languages. This operates by 'nationalising' narratives and interpretative frames, ways of perceiving and evaluating, thinking and feeling. The resulting effect is the creation of a discursive play of appeals between actors of Greek-Cypriot national identity and masculinity to what it means to be a Greek-Cypriot man and how Greek-Cypriot men are to be understood.

Nationalising discourses of identity are achieved by naturalising institutional frames of reference so that political intersections become national. Then, in Greek Cyprus, hegemonic identities imply institutionally fabricated sets of experiences. Taking again as an example 'I do not forget', we see how this particular set of experiencings creates hegemonies of masculine identities. Thus, does a 'real' Greek-Cypriot man forget?

Pathways are pre-constructed, drawn and set as to how one can reach the desirable goal of being acknowledged as a Greek-Cypriot man. Nationalising sets of experiences entails naturalising ways of being. Therefore, by dominating other possible ways of 'becoming', Cypriot national identity and masculinity have been channelled towards pre-constituted pathways drawn through Greek-Cypriot institutionalised settings of 'being'.

\section{Theorising becoming}

While in Bakhtin's view (see Morris, 1994 for original text translated and for another take on Bakhtin's construction see Shephered, 1993) the subject is unfinalised, in a perpetual state of becoming, in South-Cyprus institutionally formulated discourses of conflict identities transmit to the public static identities, which are received as finalised identities of being. Institutional identities transmitted to the public, aimed at creating culture, are not designed to form individuals who may be able to alter these identities. The experience of such institutional identities could not be considered as 'identities of becoming' since this requires the individual to hold agency in the way that identity is experienced. More importantly, individuals hold limited control over the ways in which identity is prone to change in the future. For instance, a Greek- 
Cypriot man could not decide to adopt 'I do not forget' in relation to his own socio-political understanding, because 'I do not forget' has been institutionally established, represented and performed in specific ways which have created the very experience of 'I do not forget'.

In accepting Hall's theorisation that 'identities are thus points of temporary attachment to the subject positions that discursive practices construct for us all' (Hall, 2000: 19), institutional identities are discursively communicated to the population by creating 'subject positions' which individuals temporarily attach to, yet these subject positions are prone to change, as all identities are, as no-one identity remains frozen and sterilised in time. However, the agency of reconfiguration of an institutionalised identity belongs solidly to the institution. Thus, as in the example of 'I do not forget', its repeated modification since 1974 illustrates that as an institutional identity it was becoming, but through internalisation it was becoming morphed into a personal identity of being. The perpetual yet temporary attachments to subject positions that institutional structures continually construct cannot be considered an unfinalised state of becoming for the individual, rather only a perpetual state of always becoming for institutions. Then, drawing from Jenkins (1996: 133), if we are to conceptualise identity as a process, consequently we must see institutional identifications as institutionalised processes.

\section{'Self-Other' relations in institutional fabrications of identity}

Given the above theorisation on particularities offered by institutionalised discourses of identity, such fabrications become predominantly significant in the construction of Self-Other relations.

Identity construction materialises in actual social experience. Sets of experiences, as in the case of 'I do not forget' discussed earlier, are used in creating conceptualisations of identity. These two intersect, in South Cyprus, through the institutionalisation of identity, providing the tropes by which one can acquire a Greek-Cypriot identity. In the internalisation of institutional identities there is also an internalisation of the tropes of conceptualisation. I argue that in the internalisation of the institutionally supported identities there is also an internalisation of the 
dialogics of Self (in this case, not dialogic but static) and relationship of Self to Other this creates. 'Self to Self' is defined here as the internalised spectrum through which one can perceive, choose or not and practice the possible or non-possible ways of being a man, see himself as a man, and also the spectrum through which one can see and define himself as a Greek-Cypriot man.

Then, 'Others' are here being defined in a duality of 'Otherness'; The 'Others' by whom the nation feels as being threatened (the 'enemies' of the Nation, i.e. the Greek-Cypriot notion of Turks in this instance) and the 'Others' who constitute the Nation. The latter is seen as taking effect in two forms; the Others which one needs to protect (for example the mothers of the missing persons) and the Others one needs to position himself in opposition to (for example, alterative and subordinated masculinities (Connell 1995), by reference to which 'hegemonic masculinity' is constituted, such as homosexuals and other coexisting masculinities deviating from the hegemonic model, including Turkish-Cypriot masculinities). What is at stake then, is the effect of the conceptualisation and subsequent materialisation of these identities on the relationship of 'Self to Self' and the relationship of 'Self to Others'.

The understanding of one's Self does not primarily arise through a sterilised context of rational individuality. Rather, as Gardiner (1992: 165) describes Bakhtin, the phenomenon of 'self-ness' is constituted through the operation of a dense and conflicting network of discourses, cultural and social practices and institutional structures, which are themselves bound up with the intricate phenomenology of the Self-Other relation. The way that institutionalised claims of national identity intersect with mainstreaming drives to gender is at the individual level, the way in which an aspect of the self intersects with another aspect. Hence, the way that national identity is institutionally and largely understood in relation to some Other, is the way the understanding of Self is fabricated to intersect with that Other both internally within the Self and externally with the social or national Other. In the context of the institutional fabrication of the dialogic of Self-Other relation, what is at stake is the non-plasticity of the projected identities resulting in non-plasticity to the relationship of 'Self to Self' and 'Self to Others'. Thus, the projection of 
these institutional identities has a static effect on the formation and practice of Greek-Cypriot national identity and masculinity (within the Nation), and such conceptualisations shape GreekCypriot society's relationship to the Others.

In this context, the question raised by Judith Butler 'If gender is constructed, could it be constructed differently, or does its contractedness imply some form of social determinism, foreclosing the possibility of agency and transformation?' (1990: 7), opens up a further theoretical discussion related to the above argument.

Fixed unitary conceptualisations of 'being' are necessary for effective political actions and politically desired goals. As Butler (1990: 16) argues, coalitional politics requires neither an expanded category of 'men', in this instance but gender categories in general, nor an internally multiplicious Self that offers its complexity at once. On the contrary, certain political practices institute identities on a contingent basis in order to accomplish whatever aims are in view, (ibid). Given that coherence and continuity of person-Self are not logical and their experiences could only be illusional they could only, borrowing Butler's words, be 'socially instituted and maintained norms of intelligibility' (ibid: 17).

For politics of differentiation and exclusion to take place, both sense of unity and stability of the unity projected through a particular identity, need to be established and secured. Without the goal of "unity", other possible identities could rise in the process of political action, not aiming at homogenous unitary identities, but rather at expressions of Self or groups of Selves. Such provisional unities or, at the individual level, realisations of Self, may shake the illusions of stable and unitary identities and not aim to accomplish, but inadvertently threaten to disrupt the implicit political aims for which these unitary identities and identities of Self have initially been constructed. As an open coalition 'will affirm identities that are alternately instituted and relinquished according to the purposes at hand; it will be an open assemblage that permits of multiple convergences and divergences without obedience to a normative telos of definitional closure' (Butler, 1990: 17). 
Institutional identities have traditionally functioned in these particular processes. As argued above, fixed conceptualisations of being are necessary for political goals. 'I do not forget' provides us with a clear illustration of how the manufacturing of particular institutional identities has served the post-war Greek-Cypriot political struggle of creating an entrenchment of identity, which would have been sustained in the way originally formed. 'I do not forget' is the most obvious institutionalised Greek-Cypriot identity pointing directly to the national urgency for survival. Moreover, as a national slogan, it has successfully predominated Greek-Cypriot collective everyday consciousness as illustrated by its repeated occurrence in everyday life and conversations taking place within it and also in the extent to which it is visually represented and performed by individuals who do not belong or formally correspond in and to institutions. The discourses of 'I do not forget' crystallise a common national understanding, by the means of constructing and sustaining an identity based on a particular frame of reference: We have been victims of the enemy and that, we will not forget.

\section{Conclusion}

In this article I argued that in post-war South Cyprus, the institutional political struggle rested on cultivating a common national goal, through the consolidation of a shared static identity, which leads to a specific Greek-Cypriot collective understanding of the conflict. A static and unchangeable understanding of one's Self is needed in order to create a picture of the politically desirable 'enemy' (the 'Other' as an enemy that performs that very function, i.e. as threatening, uncivil and so forth). Hence, in serving the political goals in view, a secured identity is needed, in opposition to which this 'enemy' is constructed.

As noted above, 'I do not forget' is understood as taking action through inter-institutional dialogues, without being limited to a single institutional setting. Then, it is about how 'I do not forget' operates through meticulous institutional support of particular constructions of national identity, mobilised through gender, and the way in which the military takes up some of these 
impulses and constructs specific militarist masculinities. Yet, institutions do not solidly transmit to the population static identities of being; rather they create impulses, which may be taken up to internally construct conscientious specific identities of being, at the expense of political goals, articulated at the institutional level. As argued, the Greek-Cypriot military takes up some of these impulses and constructs specific militarist masculinities.

Basic military training is perceived as helping to teach the form of masculinity demanded by national militaries. In extending this perspective, some suggested that the military's first goal is to teach manhood and, only secondarily, teach soldiering (see Baritz, 1985: 171). Yet, absorption of the masculine discourse is crystallised through the denigration of difference. As Whitworth notes 'it is not by coincidence that the insults most new recruits face are gendered, raced, and homophobic insults: young soldiers are learning to deny, indeed to obliterate, the 'other' within themselves' (2004: 161).

The discursive and material practices, to which the new recruits are introduced, are designed to "fix' meaning, or produce a truth, in which all soldiers are expected to participate' (Whitworth, 2004: 162). These masculine representational practices, which construct the GreekCypriot soldier, as noted above, are played in a negative opposition to the 'Other', and also 'construct the 'self' vis-à-vis this other' (Doty, 1996: 10). However, as noted by Whitworth, in order for these truths that are 'fixed through these processes to remain intact, self and other must remain both distinct and separate' (2004: 155).

Certainly the non-flexibility of the identity by which Greek-Cypriot soldiers are infused raises concerns about the contact or non-contact with the Others, those opposed to whom the Self is constructed. These Others, however, exist in a duality; the real or imaginary 'Others' and the 'Others' within the Self, which the identity has also been constructed in opposition to. The masculine discourse, which is projected onto Greek-Cypriot soldiers, raises concerns about both the relationship with 'Others' but also to the constructed Self - in suppressing its internal otherness - under this process of indoctrination. As Fetherston notes, 'the power of discourse is 
to render 'right', 'legitimate', 'taken-for-granted', 'natural' specific ways of knowing, acting and organizing social life... Crucially, this rendering of 'right' silences other possibilities (they are unknowable since they are not possible)' (2000: 190), hence creating a plethora of potential troubles for soldiers whose Self may not correspond to such dominant discourses.

Greek-Cypriot men who have a father of Cypriot extraction are obligated to become soldiers at the age of 18 . Yet, military identities are not assumed to be adopted and internalised to the same extent by everyone, nor are carried and performed everlastingly by all Greek-Cypriot men in their everyday lives. Still, they are supported and reproduced at the cultural level of everyday Greek-Cypriot life - although Connell and Messerschmidt (2005) offer a key point here, in that what most men support is not necessarily who they $\operatorname{are}^{8}$.

In sum, to naturalise discourses of military masculinities is to undermine gender agency and possibilities. Evidently, most Greek-Cypriot men are not going around in their lives being soldiers as there 'is a distance, and a tension, between collective ideal and actual lives... yet very large numbers of men are complicit in sustaining the hegemonic model' (Carrigan, Connell, and Lee, 1985: 112-3). The military in South Cyprus has been more than anything else a means and ends in politics. It has been mobilised in the course of the post-war nationalist discourse to shape a society that creates men as defenders (but has failed and produced fragmented passive masculinities), women as victims and a conceptually feminine Nation, which results in creating a Nation unable to overcome any traumas as it has been conceptually anchored to 'not forget'.

8 Furthermore, the authors argue that the public face of hegemonic masculinity is not necessarily what powerful men are, but is what sustains power, and is what large numbers of men are motivated to support because it benefits them, (Connell 1983: 1856). Therefore, as Connell (1995) notes in his book Masculinities the most powerful holders' of the cultural ideal of 'hegemonic masculinity' are not inevitably the most powerful individuals. In Hearn's rendition of Connell's views, "indeed the individual holders of power may be very different from those who represent hegemonic masculinity as a cultural idea" (2004: 57). 
Networking Knowledge: Journal of the MeCCSA Postgraduate Network, Vol. 4, No. 1 (2011)

\section{References}

Anthias, F. (1989). Women and Nationalism in Cyprus In: N, Yuval Davis and F, Anthias, (Eds.), Woman- Nation- State. Basingstoke, Hampshire: Macmillan.

- (1992). Ethnicity, Class, Gender and Migration. Aldershot: Avebury.

Baritz, L. (1985). Backfire: A History of How American Culture Led Us into Vietnam and Made Us Fight the Way We Did. New York: William Morrow.

Barth, F. (1969). Ethnic Groups and Boundaries. London: George Allen \& Unwin.

Benwell, B. and Stokoe, E. (2006). Discourse and Identity. Edinburgh University Press.

Berger, L. and Luckmann, T. (1973) The Social Construction of Reality: A Treatise in the Sociology of Knowledge. London: Penguin.

Billing, M. (1995). Banal Nationalism. London: Sage.

Brubaker, R. (1996). Nationalism reframed: nationhood and the national question in the new Europe. Cambridge: Cambridge University Press.

Bryant, R. (2008), Writing the Catastrophe: Nostalgia and Its Histories in Cyprus. [Electronic version] Journal of Modern Greek Studies. Vol. 26 (2), p.p. 399- 422.

- (Summer 2005). 'Dangerous trend in Cyprus,' [Electronic version] Middle East Report 235. (Retrieved November 18, 2009). Available from: http://www.merip.org/mer/mer235/bryant.html. p. 56

Bulmer, M. and Solomos, J. (1999). Ethnic and racial studies today. London and New York: Routledge.

Butler, J. (1997). Excitable speech: A politics of the performative. London: Routledge.

- (1990) Gender Trouble: Feminism and the Subversion of Identity. New York and 
Networking Knowledge: Journal of the MeCCSA Postgraduate Network, Vol. 4, No. 1 (2011)

London; Routledge.

Calhoun, C. (1997). Nationalism (Concepts in the Social Sciences). Maidenhead:

Open University press.

Carrigan, T., Connell, R.W. and Lee, J. (1985). Towards a New Sociology of Masculinity. [Electronic version] Theory and Society Vol. 14(5). p.p. 551-604.

Cockburn, C. (2004). The line: Women, Partition and the Gender Order in Cyprus. London: Zed Books.

Christou, M. (2006). A Double Imagination: Memory and Education in Cyprus. [Online version] Journal of Modern Greek Studies Vol. 24 (2) p.p. 285- 306.

- (2007). The Language of Patriotism: Sacred History and Dangerous Memories. [Online version] British Journal of Sociology of Education Vol. 28 (6) p.p. 709- 722.

Connell and Messerschmidt. (2005). Hegemonic masculinity: Rethinking the Concept. [Online version] Gender \& Society Vol. 19 (6) p.p. 829- 859.

Connell, R. (1995). Masculinities. Cambridge: Polity Press.

- (1983) Which way is up: essays on sex, class and culture essays on sex, class and culture. Sydney: Allen \& Unwin.

Demetriou, O. (2007). To cross or not to cross? Subjectivization and the absent state in Cyprus. [Electronic version] Journal of the Royal Anthropological Institute Vol. 13 (4) p.p. 987-1006.

Doty, L. (1996). Imperial Encounters. Minneapolis: University of Minnesota Press.

Fetherston, A.B. (2000). Peacekeeping, conflict resolution and peace building: A reconsideration of theoretical frameworks. International Peacekeeping Vol. 9 (1). p.p. 190- 218.

Foucault, M. (1983) [1982]. The subject and power. In: H. L. Dreyfus and P. Rabinow (Eds.), 
Networking Knowledge: Journal of the MeCCSA Postgraduate Network, Vol. 4, No. 1 (2011)

Michel Foucault: Beyond Structuralism and Hermeneutics (pp. 208-226). University of Chicago Press: Chicago.

- (1991) [1979] Govermentality. In: G. Burchall, C. Gordon and P. Miller (Eds.), The Foucault effect: studies in governmentality. (pp. 87- 104). London: Harvester Wheatsheaf.

- (1980) Power/Knowledge: Selected interviews \& Other Writings 1972-1977. Ed. C. Gordon. Trans. C. Gordon, L. Marshal, J. Mepham, and K. Sober. New York: Pantheon Books.

Gardiner, M. (1992). The Dialogics of Critique: M.M. Bakhtin and the Theory of Ideology. London and New York: Routledge.

Gramsci, A. (1971). Selections from the Prison Notebooks of Antonio Gramsci. (Q, Hoare and G. N. Smith ,Trans.) New York: International Publishers.

Goffman, E. (1963). Stigma: notes on the management of spoiled identity. New Jersey: Prentice Hall.

Hall, S (2001) The spectacle of the 'other'. In: S ,Hall, (Ed.), Representation: Cultural Representations and Signifying practices (pp. 223- 290). London, Thousand Oaks and New Delhi: Sage.

- (2000). Who needs 'identity'? In: P. Due Gay, J. Evans and P. Redman (Eds.), Identity: a reader (pp.15-30). London, Thousand Oaks and New Delhi: Sage.

- (1977). Culture, the Media, and the "Ideological Effect", In: J. Curran, M. Gurevitch and J. Woollacott, (Eds.), Mass Communication and Society London (332-333). Thousand Oaks and New Delhi: Sage.

Habermas, J. (1987). The philosophical discourse of modernity. (Z, Vorlesungen, Trans.) London: Polity. (Der philosophische Diskurs der Moderne 1985) 
Networking Knowledge: Journal of the MeCCSA Postgraduate Network, Vol. 4, No. 1 (2011)

Hadjipavlou, M and Mertan, B. (2010). Cypriot Feminism: An Opportunity to challenge Gender Inequalities and Promote Women's Rights and a Different Voice. [Electronic version] The Cyprus Review Vol. 22 (2) p.p. 246- 268.

Hadjipavlou, M. (2006). No permission to Cross: Cypriot Women's Dialogue across the Divide [Electronic version] Gender Place and Culture Vol. 13 (44) p.p. 329- 351.

Hadjipavlou, M (2007) The 'crossings' as part of citizens' reconciliation efforts in Cyprus? Innovation Vol.20 (1) p.p. 54- 73.

Hearn, J. (2004) From Hegemonic Masculinity to the Hegemony of Men [Electronic version] Feminist Theory Vol. 5 p.p. 49-72.

Hobsbawm, E (1983) [1917]. Introduction: Inventing Traditions. In: E, Hobsbawm and T, Ranger (Eds.), The Invention of Tradition (1-14). Cambridge: Cambridge University Press.

Jenkins, R. (1996). Social identity. London and New York: Routledge.

Kedourie, E. (1994) [1960]. Nationalism. Oxford: Blackwell.

Mavratsas, C.V. (1999) National identity and consciousness in everyday life: towards a sociology of knowledge of Greek- Cypriot nationalism. [Electronic version] Nations and Nationalism Vol. 5 (1) p.p. 91- 104.

- (1996). Approaches to nationalism: basic theoretical considerations in the study of Greek- Cypriot case and a historical overview. Journal of the Hellenic Diaspora Vol. 22 (1) p.p. 77- 102 .

Morris, P. (Ed.) (1994). The Bakhtin Reader: Selected Writings of Bakhtin, M.M [1895- 1975], Medvedev, P.N [1891- 1938]. Voloshinov. London: Edward Arnold.

Morton, D. (1971). Unravelling Gramsci hegemony and passive revolution in the global political economy. London: Pluto. 
Networking Knowledge: Journal of the MeCCSA Postgraduate Network, Vol. 4, No. 1 (2011)

Nagel, J. (1998). Masculinity and Nationalism: Gender and sexuality in the Making of Nations [Electronic version] Ethnic and Racial studies Vol. 21 (2) p.p. 242-69.

Ozkirimli, U. (2005). Contemporary debates on nationalism: A Critical Engagement. New York: Palgrave MacMillan.

Papadakis, Y. (2008). History Education in Divided Cyprus: A comparison of Greek Cypriot and Turkish Cypriot Schoolbooks on the "History of Cyprus". Nicosia: Prio.

- (2005). Echoes from the Dead Zone. London: IB Tauris.

Sant Cassia, P. (2006) Guarding Each Other's Dead, Mourning One's Own: The problem of Missing Persons and Missing Pasts in Cyprus. South European Society and Politics, Vol. 11 (1) p.p. $111-128$.

- (2005) Bodies of Evidence: Burial, Memory and the Recovery of missing Persons in Cyprus, p.71.

Scott, D. (1995). Colonial Govermentality. [Electronic version] Social text Vol. 43 p.p. 191-220.

Shephered, D. (Ed.) (1993) Bakhtin: carnival and other subjects' [Electronic version] Critical studies Vol. 3 (2) Amsterdam and Atlanta: Rodopi B.V.

Spyrou, S. (2002). Images of "The Other": "The Turk" in Greek Cypriot Children's Imaginations. [Electronic version] Race, Ethnicity and Education. Vol 5 (3) p.p. 255-272.

Whitworth, S. (2004). Men, Militarism \& UN Peacekeeping: A Gendered Analysis. Colorado: Lynne Rienner.

Yakinthou, C. (Spring 2008). The Quiet Deflation of Den Xehno? Changes in the Greek Cypriot Communal Narrative on the Missing Persons in Cyprus. The Cyprus Review: Journal of Social, Economic and Political Issues Vol.20 p.p. 15-33.

Yuval-Davis, N. (1998). Beyond differences: women, empowerment and coalition politics. In: N, 
Networking Knowledge: Journal of the MeCCSA Postgraduate Network, Vol. 4, No. 1 (2011)

Charles and H, Hintjens (Eds.), gender, ethnicity and political ideologies (168- 189). London and New York: Routledge. 